\title{
BREVE PROPOSTA PARA O ENSINO DE LEITURA NA EDUCAÇÃO PROFISSIONAL
}

\author{
Glória de Fátima Pinotti de Assumpção ${ }^{1}$
}

\begin{abstract}
Resumo: Trabalhar a leitura em contextos específicos vem sendo bastante discutido nos meios acadêmicos. A educação profissional destaca-se, por si, nesse contexto. Este trabalho apresenta uma proposta de ensino de leitura em aulas de língua materna na educação profissional.
\end{abstract}

Palavras- chave: ensino de leitura, contextos específicos.

\section{A problemática}

Como professora da educação profissional, trabalhamos com alunos, a maioria egressos da oitava série, que apresentam problemas de formação estrutural. Esses problemas inviabilizam o estabelecimento de relações conceituais e os impedem, muitas vezes, de conhecer as próprias profissões, objeto dos cursos. Observamos, também, nesse período, que as causas podiam estar na sala de aula de educação profissional, em razão de que o professor não dispunha de material para desenvolver as várias competências voltadas às áreas profissionais desse sistema de ensino. Assim, optamos por introduzir atividades de leitura de textos específicos na prática diária das aulas de língua materna, de modo a possibilitar aos alunos a identificação das atividades exercidas no mercado de trabalho. Decidimo-nos pelo gênero entrevista e aplicamos atividades de leitura, pautadas no tripé sensibilização, descoberta e exploração, associadas a estratégias específicas (Solé, 1998).

O ensino de leitura, a partir da observação que nos remete aos gêneros discursivos (Bakhtin, 1992), permite associar os textos às práticas sociais. Em sala de aula, com os alunos da educação profissional, essa prática ajudou, também, a reforçar o fato de que o ensino de leitura em contextos específicos, sobretudo, aponta para caminhos alternativos de superação de lacunas no conhecimento, ou melhor, para a ampliação do conhecimento enciclopédico (Maingueneau, 2001), no que se refere às atividades passíveis de serem exercidas na vida em sociedade.

\section{Metodologia e seqüência didática}

Buscamos (cf.quadro1, abaixo) selecionar um tripé para praticar leitura em sala de aula, com o objetivo de que os alunos caracterizassem objetos a partir da construção de sentidos.

\footnotetext{
${ }^{1}$ Mestre em Lingüística aplicada pela Universidade de Taubaté. Professora de educação profissional.
} 
Quadro 1

\begin{tabular}{|l|l|l|}
\hline $\begin{array}{l}\text { Etapas / Procedimentos } \\
\text { metodológicos }\end{array}$ & $\begin{array}{l}\text { Estratégias de } \\
\text { Leitura }\end{array}$ & $\begin{array}{l}\text { Resultados } \\
\text { Obtidos }\end{array}$ \\
\hline Sensibilização & Seleção & $\begin{array}{l}\text { Percepção da superestrutura } \\
\text { do texto }\end{array}$ \\
\hline Descoberta & $\begin{array}{l}\text { Questionamentos/ } \\
\text { Sublinhamentos }\end{array}$ & $\begin{array}{l}\text { Exploração do texto promovendo a } \\
\text { aproximação do significado. }\end{array}$ \\
\hline Exploração & $\begin{array}{l}\text { Construção de pontes } \\
\text { para o real significado }\end{array}$ & Desenvolvimento de postura crítica \\
\hline
\end{tabular}

Nessas atividades de leitura, os alunos leram os seguintes textos de entrevistas, interpretando algum aspecto do mundo profissional:

1. Um Eterno Principiante - texto de Fernando Sabino, publicado pela Synthesis. Revista de Educação. Ano 1, nº 1, CEETEPS. Copidart: São Paulo, 1991.

2. A pele brasileira e suas peculiaridades - texto produzido pelo cirurgião plástico João Magalhães, publicado pela Revista Colóquio. S.d.

3. Primeiro Astronauta Brasileiro - Major-Aviador Marcos César Pontes publicado pela revista Aerovisão. Ano XXVIII, nº 200. CECOMSAER. Brasília: 2000.

Dividimos a sala em duplas. Cada dupla escolheu uma entrevista. Pedimos que o aluno lesse a entrevista. Em seguida, sugerimos atividades de sensibilização, como indicamos no Quadro 2.

Quadro 2

Atividade - Sensibilização - Preparação para estudo do tema

O que é uma entrevista?

Quais temas podem são tratados em uma entrevista?

Para que serve esse gênero de texto?

Como se faz uma entrevista?

Cite alguns tipos de entrevistas que já tiveram oportunidade de ler/conhecer.

Iniciamos pelo levantamento do que os alunos já conheciam sobre o gênero, garantindo a introdução da proposta da aula.

Para a descoberta do texto - etapa seguinte -, aplicamos um roteiro de leitura em forma de conversa. Essa estratégia permitiu-nos despertar no aluno o interesse para o tema em questão. Vejamos o quadro a seguir.

Quadro 3

Atividade - Descoberta

Examinando o título dessa entrevista, é possível deduzir qual é a área profissional do entrevistado?

Se o título não é esclarecedor, qual trecho permite reconhecer a profissão de que tratará a entrevista? 
Faça a leitura do texto que antecede a entrevista escolhida, para identificar o local de trabalho do entrevistado.

Por ser a entrevista um gênero discursivo de natureza interativa por excelência (cf. Maingueneau, 2001), optamos por uma atividade de leitura que auxiliasse a levar o aluno a posicionar-se como o locutor que coordena as enunciações junto ao entrevistado. Essa atividade incentivou os alunos a se interessarem ainda mais pela proposta da aula.

Partimos, então, para a outra etapa. Discutimos sobre as revistas e encaminhamos atividades que permitissem aos alunos a exploração das características dessas revistas. Neste ponto da questão, conduzimos o aluno a refletir a respeito de que a publicação está associada aos interesses da sociedade, ao desenvolvimento das profissões, entre outros, utilizando-nos do seguinte encaminhamento:

Quadro 4

Atividade - Exploração

a) O que objetiva a divulgação dessas entrevistas?

b) Observe a fala do entrevistado e tente responder como é feita a seleção de um profissional.

c) Observe em que revista está sendo publicada a entrevista, para identificar essa publicação com o local de trabalho.

d) Aponte o nome da revista e descubra a relação do editor com a profissão do entrevistado.

Encerramos esse trabalho com a atividade sugerida a seguir.

Quadro 5

Atividade - Apresentação da entrevista analisada

a) Quais profissões são exercidas pelos entrevistados?

b) Apresente trechos da entrevista em que são identificáveis características de profissões.

c) Se fôssemos entrevistar esses profissionais, quais perguntas ligadas à sua área de atuação ainda poderiam ser feitas?

\section{Considerações finais}

Sem dúvida, a leitura dos textos permitiu-nos conduzir esses alunos a uma prática de leitura contextualizada. Ao distribuir as tarefas, percebemos que a produção de leitura iniciou-se imediatamente.

Os alunos exploraram o texto criteriosamente e conseguiram aproximar o tema da entrevista à atividade profissional exercida. Gratificou-nos observar que, por intermédio dessas atividades de leitura, o aluno estabeleceu relação entre a área profissional e o mercado de trabalho, relação essa criada pelo próprio aluno como resultado de uma leitura com compreensão.

A roteirização da leitura foi um procedimento metodológico empregado para o desenvolvimento desse trabalho, associada às estratégias de leitura apresentadas no tripé 
sensibilização, descoberta e exploração. A atividade final permitiu-nos avaliar o grau de compreensão de leitura produzida pelos alunos.

Tornar possível o ensino da leitura em contextos específicos é apenas uma questão de se estabelecer critérios, selecionar estratégias a partir de condições contextuais determinantes. A iniciativa de examinar as entrevistas despertou, nesses alunos, o interesse em conhecer as profissões, até então, por eles desconhecidas. Podemos concluir que a escola de educação profissional pode e deve apropriar-se de tipos de textos que circulam fora de seus domínios, no mundo profissional e deve ter como critério que vale a pena oferecê-los, se não apenas a este, mas a qualquer aprendiz.

\title{
Referências Bibliográficas
}

BAKHTIN, Mikhail. Estética da criação verbal. Trad. Maria Ermantina Galvão Gomes Pereira. 3.ed. São Paulo: Martins Fontes, 2000.

MAINGUENEAU, Dominique. Análise de textos de comunicação. Tradução de Cecília P. de Souza-e-Silva, Décio Rocha. São Paulo: Cortez, 2001.

SOLE, Isabel. Estratégias de Leitura. Tradução Cláudia Schilling, 6.ed. Porto Alegre: Artmed, 1998.

\begin{abstract}
This article reports an experience on the reading-teaching in specific contexts. It presents the partial results of study and proposes a teaching of reading to be used in professional settings.
\end{abstract}

Key words: reading-teaching, specific contexts. 